\title{
Development and experiment of rice hill-drop drilling machine for dry land based on proportional speed regulation
}

\author{
Fu Wei ${ }^{1,2}$, Zhang Zhiyuan ${ }^{1}$, Zang Ying ${ }^{2}$, Luo Xiwen ${ }^{2 *}$, Zeng Shan ${ }^{2}$, Wang Zaiman ${ }^{2}$ \\ (1. College of Mechanical and Electrical Engineering, Shihezi University, Shihezi 832003, China; \\ 2. College of Engineering, South China Agricultural University, Guangzhou 510642, China)
}

\begin{abstract}
Rice precision hill-drop drilling technique in dry land uses fixed hill spacing to achieve orderly planting of crops and to attain good ventilating and day-lighting effects in rice fields. The technique is also beneficial in improving root growth and root structure and in increasing lodging resistance. The high-yield record of Xinjiang Production and Construction Corp's first division for three consecutive years shows that rice precision hill-drop drilling technique in dry land is one of the important directions to developed rice cultivating mechanization technology. To further improve the quality of rice precision hill-drop drilling machine for dry land, a single profiling, electro-hydraulic proportional real-time adjustment of system was developed according to the agronomic requirements. This machine can simultaneously finish various kinds of seedbed leveling, furrowing and seeding operations, as well as soil covering and pressing. Electro-hydraulic proportional speed regulation makes an AMESim simulation test and analyzes the stability and error of hydraulic adjusting planting distance. Bench testing was carried out on the metering device by simultaneously employing high speed photography technology and analyzing the relationship of the high speed of hill distance and seed charge height. Finally, machine trial was completed. The two-year field experiments of Xinjiang Production and Construction Corp showed that when the machine operation speed is $2.8-3.2 \mathrm{~km} / \mathrm{h}$, the sowing depth percent of pass is $75 \%$ or higher, the qualified rate of row spacing is $80 \%$ or more, the pass rate of row spacing is $90 \%$ or higher, and the quantity per hill is $75 \%$ or higher. This machine met the various indicators of hill sowing quality requirements.
\end{abstract}

Keywords: rice, hill-drop drilling for dry land, quality of precision sowing, proportional speed regulation, field experiment DOI: $10.25165 /$ j.ijabe.20171004.3125

Citation: Fu W, Zhang Z Y, Zang Y, Luo X W, Zeng S, Wang Z M. Development and experiment of rice hill-drop drilling machine for dry land based on proportional speed regulation. Int J Agric \& Biol Eng, 2017; 10(4): 77-86.

\section{Introduction}

Rice, one of the four major grain crops in China with

\footnotetext{
Received date: 2016-04-20 Accepted date: 2016-12-11

Biographies: Fu Wei, PhD, Associate Professor, research interests: fruit and vegetable harvesting machinery, Email: fuwei001@ 126.com; Zhang Zhiyuan, graduate student, research interests: mechanical design and theory, Email: 1747635862@qq.com; Zang Ying, $\mathrm{PhD}$, Associate Professor, research interests: agricultural mechanization and automation research, Email: yingzang@, scau.edu.cn; Zeng Shan, $\mathrm{PhD}$, research interests: rice production mechanization, Email: zengshan1973@yahoo.com.cn; Wang Zaiman, Assistant Researcher, research interests: rice mechanized production equipment research, Email: wangzaiman@ scau.edu.cn. *Corresponding Author: Luo Xiwen, Professor, research interests: agricultural mechanization engineering and precision agriculture. College of Engineering, South China Agricultural University, Guangzhou 510642, China. Tel: +86-13902277193, Email:xwluo@scau.edu.cn.
}

a planting area of approximately 30 million $\mathrm{hm}^{2}$ nationwide, accounts for about $30 \%$ of China's total planting area of grain crops $^{[1]}$. Rice is a staple food that feeds nearly half of the global population, including nearly all populations of Eastern Asia and Southeast Asia, as well as $65 \%$ of the Chinese population ${ }^{[2-4]}$. Rice can be planted in the following ways: direct seeding (manual, air and mechanical direct seeding) and rice transplanting (manual and mechanical transplanting). Currently, rice planting is all direct seeding in the US and $80 \%$ is dry direct-seeding ${ }^{[5]}$. Both Italy and Russia adopted 100\% mechanical direct seeding, whereas $90 \%$ of rice planting in Australia uses air seeding and $10 \%$ of that uses dry direct-seeding ${ }^{[6-8]}$. In the $1950 \mathrm{~s}$, studies on dry direct-seeding machines of rice have unfolded in northeast China and Hebei Province in succession ${ }^{[9]}$, 
whereas the Xinjiang Production and Construction Corp (XPCC) started to promote large scale mechanical dry direct-seeding technique in the $1980 \mathrm{~s}^{[10]}$. China faces severe lack of water resources, which adverse impact the production of grain crops. Precision rice dry direct-seeding technique has special advantages in saving water and increasing yield ${ }^{[11,12]}$. Therefore, rice planting areas using mechanical seeding technique has been increasing annually in China to address the water resource shortage ${ }^{[13]}$.

Dry direct-seeding, a mechanical direct-seeding technique also known as the dry seeding wet irrigation technique, mainly seeds into the seedbed through the seed metering device. Irrigation will stop after the checked basins are filled with water. The water layers will naturally decline and dry out after 3-5 d. Rice seeds saturated with water will germinate and grow in wet soil. During the seedling emergence stage, water supplementing will be carried out depending on the moisture condition of the soil. Once seedlings are made adequate, the water layers will be maintained during the two-true-leaf-and-one-terminal-bud and the three-trueleaf period, and then it will be changed to normal management. Currently, foreign and domestic rice dry direct-seeding machines generally use an outer groove wheel seed metering device for drill seeding, which has disadvantages such as shallow distribution of rice seedling roots, too dense rice seedlings in middle and later stages, poor ventilation and lighting conditions, as well as elongated, thin and tender portion between the first and second sections that will lead to lodging in later stage of rice grouting ${ }^{[14]}$. To address the large seeding scale and easy lodging in the current direct rice seeding practice, a team led by Professor Luo Xiwen from South China Agricultural University successfully developed a precision rice hill-drop drilling machine for dry land. Using the single profiling technique for furrowing, seeding and soil covering, this machine could adjust seeding amount and row spacing, and could apply real-time control on hill spacing upon seeding requirements. This machine can complete a 20-row precision seeding in one operation. The rice hill-drop drilling for dry land technique can realize orderly planting, decent field ventilation and lighting, low impact from diseases and pests, hill-drop drilling for dry land, improved ability of plants to absorb nutrients, and resistance to lodging ${ }^{[15]}$.

\section{Overall structure and agronomic requirements of the rice hill-drop drilling machine for dry land}

The single profiling 2BDH-20 rice hill-drop drilling machine for dry land was developed according to the agronomy of rice hill-drop drilling for dry land and the technical requirements of the supported tractor with a 40-44 kW power.

\subsection{Agronomic requirements}

Rice hill-drop drilling for dry land technique completed its demonstration experiment on production in XPCC for three consecutive years, adopting the rice hill-drop drilling for dry land agronomic techniques and the requirements of the First Regiment, First Division of $\mathrm{XPCC}^{[16,17]}$.

Field leveling requirements before seeding: before spring seeding, furrow the field at 200-250 $\mathrm{mm}$ to remove the stubble. Apply base fertilizer (manually apply $50 \mathrm{~kg}$ of calcium phosphate or $15 \mathrm{~kg}$ of diammonium orthophosphate) at a depth of $60-80 \mathrm{~mm}$. Use a combined land preparation machine to prepare the land in order to ensure fine soil and leveled land without residual films. Use a laser leveling machine to level the ground and ensure that the elevation difference of the field surface is between $30-50 \mathrm{~mm}$.

The seeding parameters of rice hill-drop drilling machine for dry land in Xinjiang are as follows: equal row spacing is $200 \mathrm{~mm}$; hill spacing is $100 \mathrm{~mm}$; seeding amount is $10-12 \mathrm{~kg} / 667 \mathrm{~m}^{2}$; controlled seeding depth is $10-20 \mathrm{~mm}$; soil covering thickness is $10 \mathrm{~mm}$; and qualification rate per hill is $\geq 75 \%$ and qualification rate of hill spacing is $\geq 80 \%$.

\subsection{Overall structure of precision rice hill-drop drilling machine for dry land}

The precision rice hill-drop drilling machine for dry land mainly consists of the mechanical and electro-hydraulic proportional speed adjustment systems. The mechanical system mainly includes the following: suspension bracket, framework, land wheels, gearbox, 
row marker and seeding unit. This system primarily functions to complete land leveling, furrowing, and precision rice seeding, soil covering and compacting.

The structure of the $2 \mathrm{BDH}-20$ precision rice hill-drop drilling machine for dry land is shown in Figure 1. Table 1 shows the main technical parameter. The electro-hydraulic proportional speed adjustment system mainly realizes the real-time adjustment of hill spacing when the traveling speed of the tractor changes; the electro-hydraulic proportional speed adjustment system includes two sub-systems, namely, electronic control and hydraulic systems ${ }^{[18,19]}$.

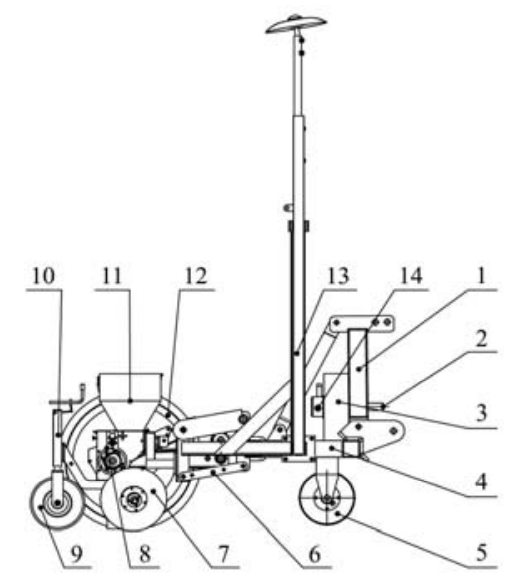

a. Side view

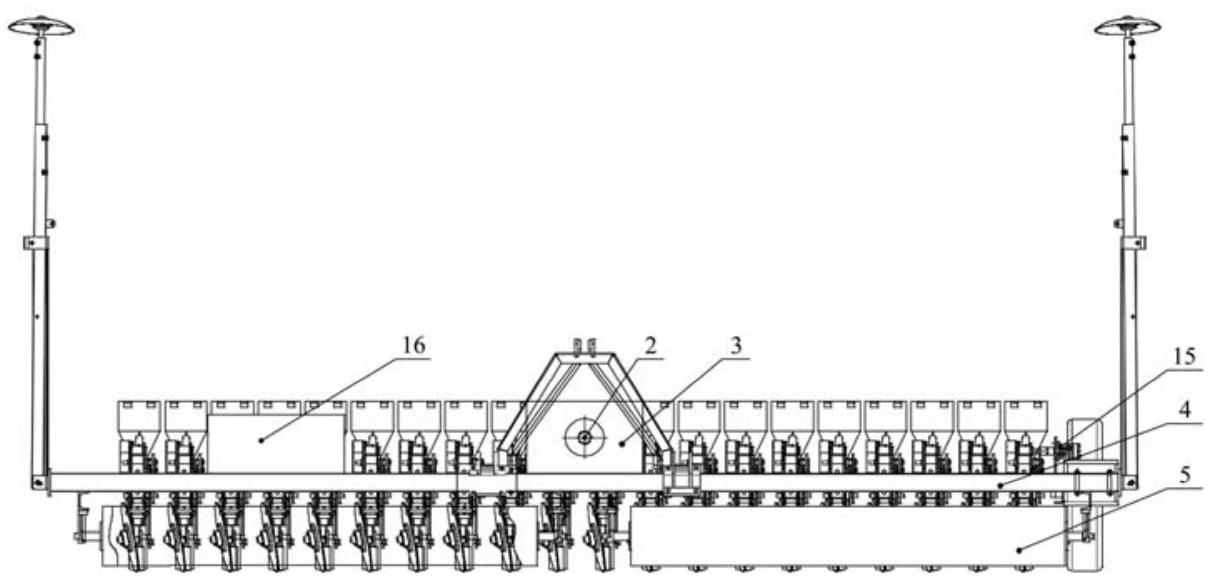

b. Front view

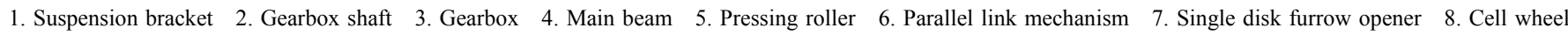
seed metering device 9. Depth wheel 10. Depth wheel adjustment mechanism 11. Seed cabinet 12. Land wheels 13. Row marker 14. Hydraulic pump 15. Hydraulic motor 16. Oil tank

Figure 1 Structure of the $2 \mathrm{BDH}-20$ precision rice hill-drop drilling machine for dry land

Table 1 Main technical parameter of $2 \mathrm{BDH}-20$ precision rice hill-drop drilling machine for dry land

\begin{tabular}{lc}
\hline \multicolumn{1}{c}{ Parameters } & Value (mode) \\
\hline Linkage type & Suspension \\
Overall dimensions $(\mathrm{L} \times \mathrm{W} \times \mathrm{H}) / \mathrm{mm}$ & $1750 \times 4200 \times 2667$ \\
Overall weight $/ \mathrm{kg}$ & 1100 \\
Power $/ \mathrm{kW}$ & $\geq 40$ \\
Operating speed $/ \mathrm{km} \cdot \mathrm{h}^{-1}$ & $2.8-4.0$ \\
Number of seeding rows & 20 \\
Row spacing $/ \mathrm{mm}$ & $150-250$ \\
Hill spacing $/ \mathrm{mm}$ & $80-150$ \\
Seeding depth $/ \mathrm{mm}$ & $10-20$ \\
Soil covering thickness $/ \mathrm{mm}$ & 10 \\
Metering mode & Hill-drop \\
Furrow opener & Single disk furrow opener \\
Qualification rate of seeders per hill & $\geq 75 \%$ \\
Qualification rate of hill spacing & $\geq 80 \%$ \\
\hline
\end{tabular}

The electronic control system consists of two hall sensors and one PLC. The hall sensors could be used to measure the rotation speeds of the land wheels and of the seed metering device. The PLC controls the openness of the proportional flow valve's oil outlet and adjusts motor speed and hill spacing. The hydraulic system mainly contains the oil tank, proportional flow valve (MA-QVHZO-AES-06/18/U0), variable vane pump (VP-SF-40-D), and gerotor motor (BMR250-2BM).

\subsection{Working principle of the unit}

While the precision rice hill-drop drilling machine for dry land operates, Row Marker 13 will be lowered firstly. Under the dead load of the machine, Pressing Roller 5 will press and level the seedbed. Under the influence of Parallel Link Mechanism 6 and Depth Wheel 9, the Single Disk Furrow Opener will create 10-20 mm shallow furrows. The tractor's power output shaft transmits power to the Gearbox 3. The gearbox will then drive the Hydraulic Pump 14 for real-time adjustment of the speed of the Hydraulic Motor 15 through the electronic control hydraulic hill spacing adjustment system. In this manner, the hill spacing can be regulated. The Cell Wheel Seed Metering Device 8 will sow seeds into the seedbed per fixed hill spacing. The Depth Wheel 9 will press on the seedbed and complete a series of operations such as depth limiting, soil covering and pressing.

\section{Design of critical parts of precision rice} hill-drop drilling machine for dry land

\subsection{Electronic control system}

The electronic control system is the core part used to adjust and control hill spacing. This system is mainly 
used for real-time monitoring on the speeds of land wheels and metering device and in controlling the speed ratio of the land wheels and the seed metering device.

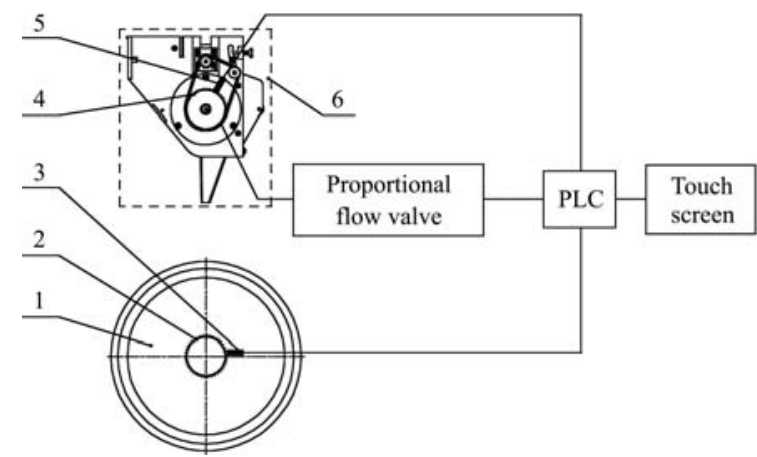

1. Land wheel 2. Land wheel speed measurement chain ring 3. Land wheel speed measurement sensor 4. Motor speed adjustment chain ring 5. Motor speed measurement sensor 6. Cell wheel seed metering device

Figure 2 Schematic of the electronic speed control system

The electronic control system includes two parts, namely, system hardware and software. System hardware mainly consists of land wheel speed measuring chain ring, land wheel speed measurement sensor (hall sensor), motor speed measurement chain ring, motor speed measurement sensor (hall sensor), PLC and touch screen. The electronic control speed adjustment system is shown in Figure 2. For seeding operation, the hill spacing value is entered in HMI. Use Land Wheels Speed Sensor 6 to monitor the land wheel speed measurement chain ring (when the land wheel speed measurement chain ring rotates with the land wheels for one turn, the hall sensor will export 20 rectangular pulse signals) and provide feedback to the PLC controller. The land wheels' speed has a fixed ratio (to be calculated by Equation (1)) to the seed metering device's rotation speed. Meanwhile, PLC controls the proportional flow valve to regulate the flow, control the hydraulic motor's speed, and measure the seed metering device's (motor) speed through the seed metering device speed measurement sensor (when the seed metering speed measurement chain ring rotates with the motor for one turn, the hall sensor will export eight rectangular pulse signals). Feedback will be provided to the PLC for real-time adjustment of the speed to ensure that when the tractor's travel speed changes, the cell wheel seed metering device's hill spacing could be subject to real-time control.

The land wheels' speed has a fixed ratio to the cell wheel seed metering device's speed. This cell wheel has eight cells in total. The hill spacing is $d(d=100 \mathrm{~mm})$ and $\delta$ is the absolute slip rate. The Equation to calculate $n$ is $^{[20]}$.

$$
\begin{gathered}
\pi D(1-\delta) \%=n\left(8 \times d \times 10^{-2}\right) \\
n=\frac{\pi D(1-\delta) \%}{8 \times d \times 10^{-3}}
\end{gathered}
$$

The diameter of the land wheels of the precision rice hill-drop drilling machine for dry land is $D=600 \mathrm{~mm}$; $\delta=\frac{S-\pi D n}{\pi D n} \times 100 \% . \quad$ Usually, $\delta=10 \%-20 \% . \quad$ This study used $\delta=10 \%$ (no load for land wheels). According to Equation (1), $n=2.12$.

\subsection{Hydraulic system simulation}

The hydraulic system is simulated based on the hydraulic system of the precision rice hill-drop drilling machine for dry land. In the AMESim simulation software, the variable vane pump (VP-SF-40-D) consists of two elements: the constant-pressure pump and the pressure limiting valve. The motor drives the constant-pressure pump. The quantified motor model is chosen. The hydraulic motor can realize forward and backward rotations. In actual operation, the motor can drive 20 seed metering devices. The seed metering device's driving force $(20-30 \mathrm{~N} \cdot \mathrm{m})$ is simplified into a loading model. The electro-hydraulic proportional flow valve consists of the pressure relief valve, throttle valve, and harmonic signal source. Set the parameters of the harmonic signal source to simulate the PLC and signal output in order to control the openness of the proportional flow valve, and thus, the flow level. Signal output will be calculated using Equation (2). Refer to Table 2 for the parameter setting of the simulation elements. The simulation model is shown in Figure 3.

$$
s_{i 1}=s_{0}+\sum_{k=1}^{\text {nharm }} \operatorname{amp}_{k} \cdot \sin \left(f_{k} \cdot t+\text { phase }_{k}\right)
$$

where, $s_{i 1}$ is the signal output; $s_{0}$ is a constant value (null, non-dimensional); $a m p$ is the amplitude (null, non-dimensional); $f$ is the frequency; phase is the phase angle $\left(^{\circ}\right)$; and nharm is the number of harmonics. The parameters of the harmonic signal source include frequency and amplitude and the changes of the phase angle are not considered. 
Table 2 Component parameters of simulation

\begin{tabular}{ccc}
\hline Simulation components & Parameters \\
\hline \multirow{2}{*}{ Constant-pressure pump } & Displacement & $200 \mathrm{cc} / \mathrm{rev}$ \\
& Speed & $1500 \mathrm{r} / \mathrm{min}$ \\
& Duration of flow rate variation & $0.05 \mathrm{~s}$ \\
& Mechanical efficiency & 0.95 \\
\hline \multirow{2}{*}{ Pressure-reducing valve } & Valve outlet opening pressure & $1 \mathrm{MPa}$ \\
& Max pressure & $7 \mathrm{MPa}$ \\
\hline \multirow{2}{*}{ Pressure-limiting valve } & Rated flow & $10 \mathrm{~L} / \mathrm{min}$ \\
& Rated pressure drop & $2 \mathrm{MPa}$ \\
\hline \multirow{2}{*}{ Throttle valve } & Opening pressure & $7 \mathrm{MPa}$ \\
& Flow gradient & $30 \mathrm{~L} / \mathrm{min} \cdot \mathrm{bar}$ \\
\hline \multirow{2}{*}{ Motor } & Max outlet diameter & $2 \mathrm{~mm}$ \\
& Max signal value & 100 \\
& Max flow coefficient & 0.7 \\
\hline \multirow{2}{*}{ Load } & Displacement & $160 \mathrm{cc} / \mathrm{rev}$ \\
& Speed & $300 \mathrm{r} / \mathrm{min}$ \\
\hline
\end{tabular}

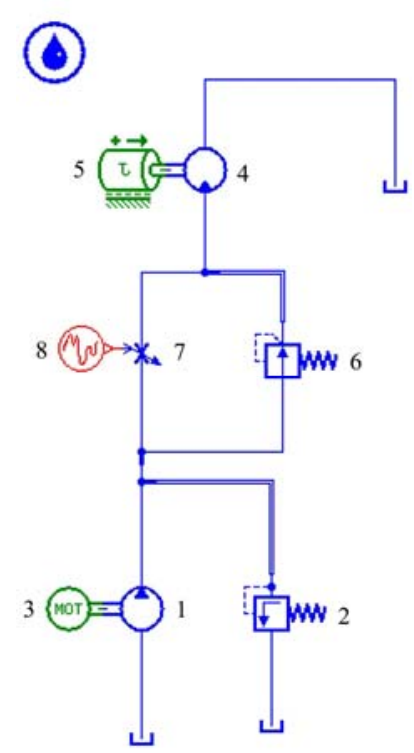

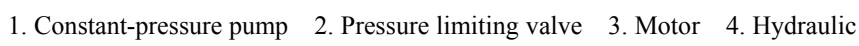
motor 5. Load 6. Pressure reducing valve 7. Throttle valve 8. Harmonic signal source

Figure 3 Simulation model of the hydraulic system

According to the simulation model above, the simulation duration was set to $10 \mathrm{~s}$ for the system. Control signals are randomly imported to the system. Through the simulation results, the system flow rate, hydraulic motor speed, and hydraulic motor's output torque are obtained.

The imported harmonic signals in the simulation process are non-dimensional random quantity and unrelated to the ratio of the seed metering device's speed to the land wheels' speed. In the simulation process, the harmonic signals only affected the flow rate change of the throttle valve, and only verified real-time control on the motor speed through other elements in order to obtain a stable motor speed.

Figure 4 is the flow rate of the hydraulic system. Under the influence of harmonic signals, the hydraulic pump, pressure relief valve, and throttle valve showed large-scale cyclical fluctuations. However, the combined effect of these three hydraulic elements basically maintained the outlet flow rate of the hydraulic motor constant. Results show that adjusting the flow rate of the proportional flow valve according to PLC can stably control the motor to set a certain speed in the system.

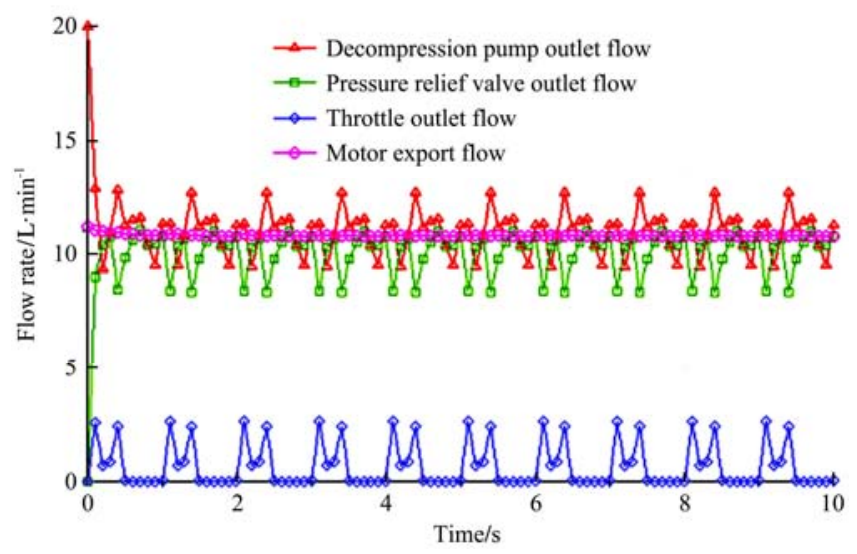

Figure 4 Flow rate of system

As shown in Figure 5, when the electro-hydraulic proportional speed adjustment system worked under the control of the harmonic signals, the hydraulic motor decreased speed. After about $1.5 \mathrm{~s}$, the motor speed began cyclical fluctuation, with each cycle lasting about $1 \mathrm{~s}$. The hydraulic motor's maximum speed is $67.62 \mathrm{r} / \mathrm{min}$ and its minimum speed is $67.08 \mathrm{r} / \mathrm{min}$. The rotation speed difference is $0.54 \mathrm{r} / \mathrm{min}$. According to the test standard of the NY/T987-2006 Operating Quality for Grain Film-covering Hill-drop Drill, the qualified range is theoretical hill spacing $\pm 15 \mathrm{~mm}$. In case of rice with $100 \mathrm{~mm}$ hill spacing, the tolerance of the hill spacing will be less than $15 \%$ to be qualified. The calculation of tolerance is shown below:

$$
\text { When } \Delta y=\frac{70-67.08}{70} \times 100 \%=4.17 \%<15 \% \text {, }
$$
results show that through electro-hydraulic proportional real-time control on speed, the hill-drop operation quality requirements can be met.

Figure 6 shows the output torque of the hydraulic motor. Under the control of the harmonic signals, the 
motor's torque dramatically increased. After about $0.2 \mathrm{~s}$, the system's motor torque began cyclical fluctuation, with each cycle being $1 \mathrm{~s}$. The maximum motor torque is $-81.48 \mathrm{~N} \cdot \mathrm{m}$ ("+" represents anticlockwise and "-" represents clockwise) and the minimum motor torque is $-54.23 \mathrm{~N} \cdot \mathrm{m}$, both more than the theoretical setting of $40 \mathrm{~N} \cdot \mathrm{m}$, showing that this system can offer a safe and reliable torque to drive the seed metering device.

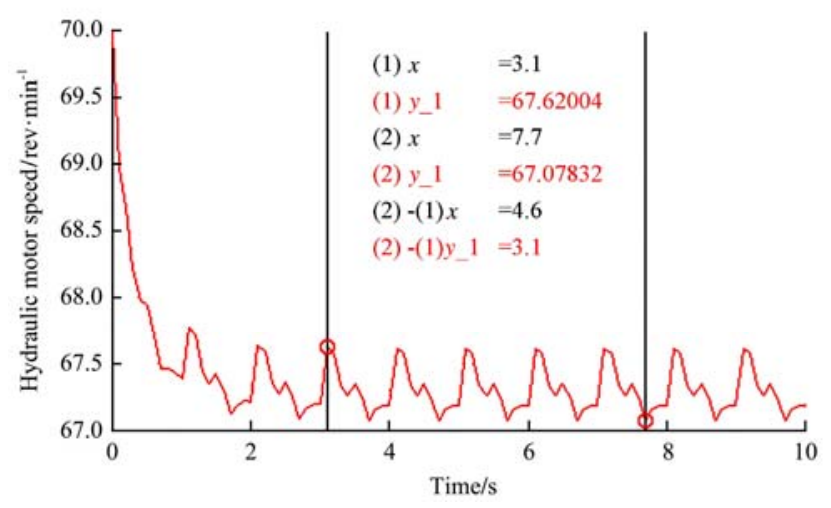

Figure 5 Speed of the hydraulic motor

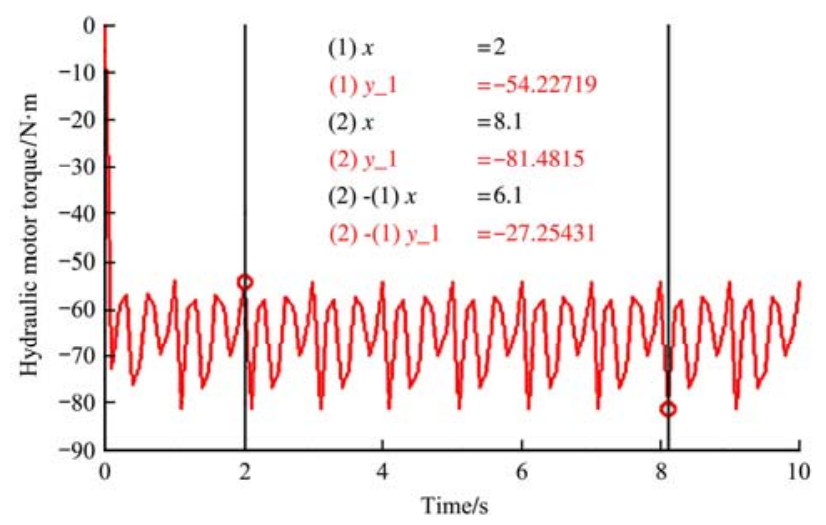

Figure 6 Output torque of the hydraulic motor

\subsection{Cell wheel seed metering device}

The cell wheel seed metering device developed by the College of Engineering, South China Agricultural University is one of the key components of the rice hill-drop drilling machine for dry land ${ }^{[22]}$. Hill formation is a major index for evaluating the seeding quality of the cell wheel seed metering device. By analyzing the hole formation property, references can be provided to decide the operating speed of the seeder and the height $(H)$ of the seed conductor above the seedbed.

3.3.1 Structure and working principle of the cell wheel seed metering device

This device mainly consists of Brush 1, Cell Wheel 3, Seed Protection Belt 4, Seed Conductor 6 and Housing. While operating, the cell wheel will start seed filling in the seed filling area and clear off the seeds by brush. Through the seed protection belt, seeds will then fall onto the seedbed through the seed conductor, as shown in Figure 7.

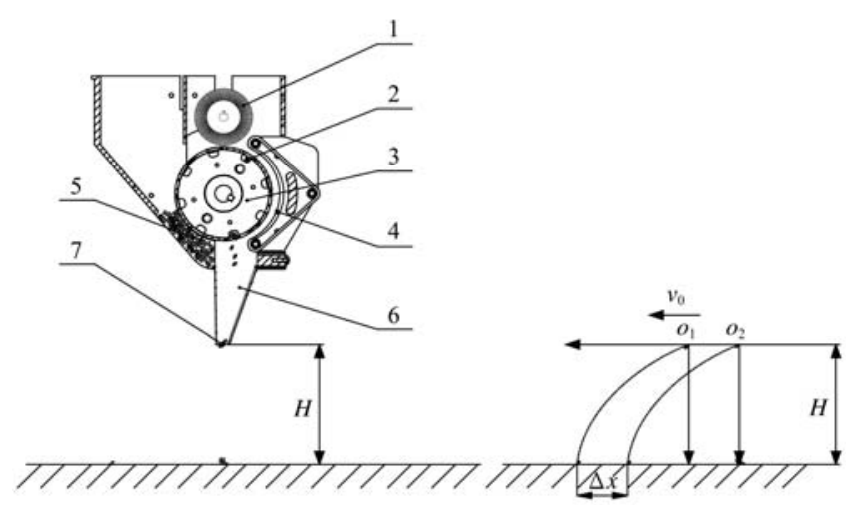

1. Brush 2. Seed-fetching cell wheel 3. Cell wheel 4. Seed protection belt 5. Seed filling area 6. Seed conductor 7. Seed conductor outlet

Figure 7 Structure of seed metering device and schematic of seeds

3.3.2 Analysis on the hill formation performance of the cell wheel seed metering device

The hill formation on the conveyor belt of the seeds of each hill falling onto the seedbed is mainly subject to the influence of the following factors: height of the seed conductor above the seedbed; operating speed of the seeder; wind resistance; bracket vibration during the seeding operation; quality and overall dimensions of the seeds; and collision of the seeds inside the seed conductor.

1) Effect of the seed conductor's height above the seedbed and operating speed of the seeder on hill formation performance

As shown in Figure 7, one of the cell wheels of the cell wheel seed metering device leaves the seed protection belt for throwing seeds. The difference between the time when the first seed begins falling onto the seedbed through the seed conductor's lower end is 7 and the time when the last seed falls onto the seedbed is $\Delta t$. The distance between the first and last seeds on the seedbed is $\Delta x$ (hill length). The first seed's origin of coordinate is $o_{1}$; the last seed's origin of coordinate is $o_{2}$; the seeder's operating speed is $v_{0}$ (assuming that each hill of seeds' initial horizontal speed out of the seed conductor's lower end is $v_{0}$ ); the seed conductor's lower end's height above the seedbed is $H$; and $v_{s}$ is the seeds' speed out of the seed conductor's lower end (assuming 
that all seeds have the same speed).

$$
\begin{gathered}
H=v_{s} t+\frac{1}{2} g t^{2} \\
\Delta x=v_{0} \Delta t
\end{gathered}
$$

Equations (3) and (4) can be used to analyze the parabolic trace of the falling seeds and the falling distance on the seedbed; through theoretical calculation, $\Delta t$ can be obtained ${ }^{[22]}$. During the experiment, $\Delta t$ is affected by the collision of the seeds inside the seed conductor and showed big difference between the theoretical and actual values. This research obtained the value of $\Delta t$ through the high-speed photography technique.

To obtain a relatively accurate value of $\Delta t$, a bench test was conducted. A cell wheel seed metering device (speed of the seed conveyor: $1.5-12 \mathrm{~km} / \mathrm{h}$ ) was fixed on the JPS-12 computer vision seed metering device performance test bench (adjustable range of the distance between the seed conductor and conveyor is $0-40 \mathrm{~mm}$ ). The rice variety used in the experiment is Gaofeng No. 1 (selected and bred by Xinjiang Academy of Agricultural Sciences; weight of 1000 grains: 26 g). TS3-100S high-speed camera (frame number for photography: 1250 frames/sec) was used to shoot the fall process of the seeds from the seed conductor outlet onto the conveyor belt (Figure 8). ProAnalyst Professional 2D object tracking and image analysis software was adopt to analyze the time difference $\Delta t$ between falling seeds. The working speed of the test bench's conveyor belt is $v_{0}{ }^{[23]}$. Equation (4) can be calculated when the seed metering device's seed conductor have different heights above the seedbed and the conveyor belt (when the seeder works) have different speeds.

The rice seeds' falling duration gradually extended as the seed conduction outlet's height $H$ above the conveyor belt pipe grew slightly. As the conveyor belt's speed (seeder's operating speed) increased, it was not affected, while increased as well. In the high-speed photography test, the conveyor belt's working speed ranged between 2.8-3.2 $\mathrm{km} / \mathrm{h}$. When the seed conductor outlet's height above the conveyor belt $H$ is $50-150 \mathrm{~mm}$, the analysis result through high-speed photography is shown in Table 3.

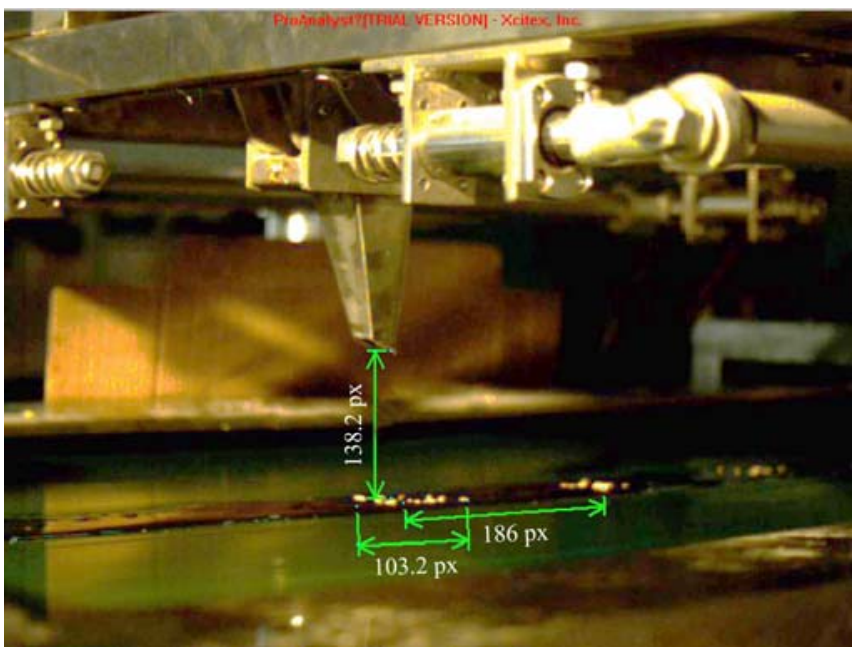

a. High-speed photograph of dropping seeds

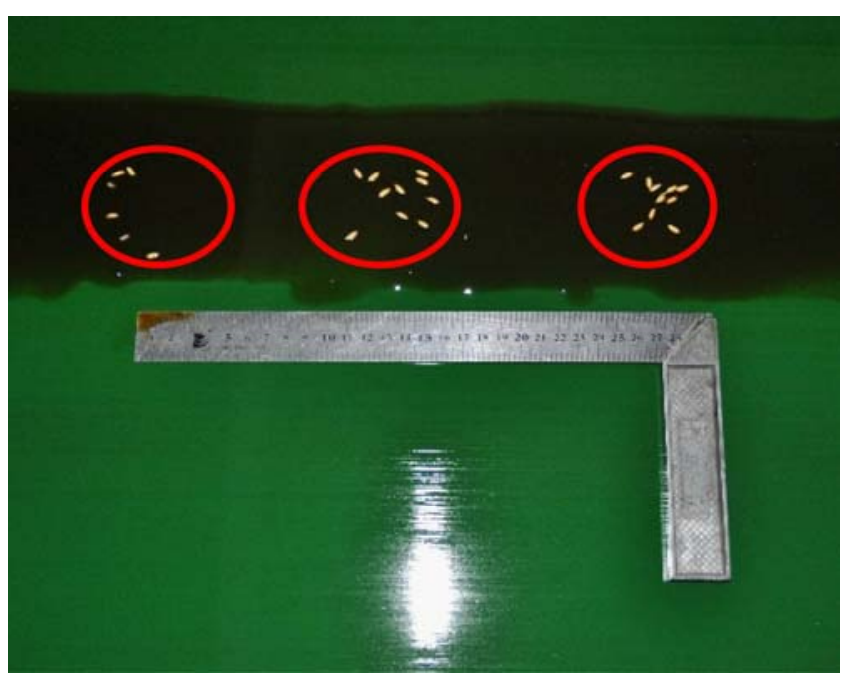

b. Seeds fall on the conveyer belt

Figure 8 High-speed photograph of the seed metering device

Table 3 Test result using a high-speed camera

\begin{tabular}{cccccc}
\hline \multirow{4}{*}{$H / \mathrm{mm}$} & \multicolumn{4}{c}{$\Delta t / \mathrm{s}$} & \multirow{2}{*}{$\begin{array}{c}\text { Variation } \\
\text { coefficient } / \%\end{array}$} \\
\cline { 2 - 5 } & Maximum & Minimum & Average & Variance & \\
\hline 150 & 0.113 & 0.0352 & 0.0547 & $8.47 \mathrm{E}-05$ & 53.21 \\
100 & 0.064 & 0.0336 & 0.0493 & $5.02 \mathrm{E}-05$ & 14.38 \\
50 & 0.056 & 0.0304 & 0.0388 & $7.50 \mathrm{E}-05$ & 22.32 \\
\hline
\end{tabular}

According to Equation (3), the maximum hill length of the seeds on the seedbed during the variation of the seed conductor's height $H$ above the conveyor belt and of the seeder's operating speed can be calculated as ${ }^{[24]}$.

$$
\begin{aligned}
& \Delta x_{\text {max }}=v_{0} \Delta t_{\text {max }}=3.2 \times \frac{1000}{3600} \times 0.1128 \times 10^{3} \\
& \Delta x_{\text {max }}=100.27 \mathrm{~mm}
\end{aligned}
$$

According to the results above, when $\Delta x_{\max }$ approaches $100 \mathrm{~mm}$, the seeding mode will be drill seeding. Therefore, the height $H$ of the outlet of the seed conductor above the seedbed will be lower than $150 \mathrm{~mm}$. 
2) Wind resistance influence

During the bench test, the cell wheel seed metering device is fixed, the conveyor belt is working, and wind resistance did not influence the falling process of the seeds. During field testing, wind resistance significantly influenced the hill formation of seeds. The higher the seed conductor is above the seedbed, the larger the wind resistance's influence became. Meanwhile, the grade of natural force considerably influenced the hill formation of seeding.

\section{3) Vibration and bouncing influences}

During seeding, the framework showed a non-linear random vibration, and the ground is uneven. Seeds fell in the cell wheel and would have more collisions in the seed conductor, affecting the hill formation of seeds on the seedbed. Meanwhile, the instant of the seeds fell on the seedbed, the seeds will hit the groove wall and bounce off, affecting hill formation. Increased plump seeds and solid soil will have a more obvious bounce. Based on the analysis above, a lower height $H$ of the seed conductor outlet above the seedbed will lead to a better hill formation. When the rice hill-drop drilling machine for dry land carried out seeding, height $H$ was $100 \mathrm{~mm}$ and operating speed was $2.8-3.2 \mathrm{~km} / \mathrm{h}$.

\section{Field experiment and analysis}

\subsection{Experiment conditions}

The experiment of the developed 2BDH-20 precision rice hill-drop drilling machine for dry land was carried out in the First Regiment, First Division of XPCC. The rice variety used in the experiment was Gao Feng No. 1. The row spacing of seeding was $200 \mathrm{~mm}$; hill spacing was $100 \mathrm{~mm}$; seeding rate per $667 \mathrm{~m}^{2}$ was $10-12 \mathrm{~kg}$; and number of grains each hill was 12 to 14 .

\subsection{Experiment methods}

NY/T987-2006 Operating Quality for Grain Film-covering Hill-drop Drill was applied as the inspection standard for field testing that uses seeding depth, hill spacing, row spacing, and number of grains every hill as the performance evaluation indexes. A $77 \mathrm{~kW}$ tractor was provided for traction at the operating speed of 2.8-3.2 km/h (Figure 9). In the experiment plot, five small areas were chosen along the diagonal lines, at the crossing point of the diagonal lines, and at the points 1/5 length of the diagonal line to each corresponding corner. Ten rows were selected in such a manner that any two rows were not immediately adjacent; each small area was $3 \mathrm{~m}$ long. Ten test points were selected for each row. This experiment mainly tested the qualification rate of seeding depth, hill spacing, row spacing, and number of grains for each hill of rice hill-drop drilling machine for dry land. According to the test standard, the qualification rate of seeding depth was $\geq 75 \%$; hill spacing's qualification rate was $\geq 80 \%$ (range within theoretical hill spacing $\pm 15 \mathrm{~mm}$ was deemed as qualified); row spacing's qualification rate was $\geq 90 \%$; and qualification rate of number of grains each hill was $\geq 75 \%$ (for crops with small size of seeds such as wheats, millets, and sugar beets, the qualification range is $n+3$ ). The measurement results are shown in Table 4.

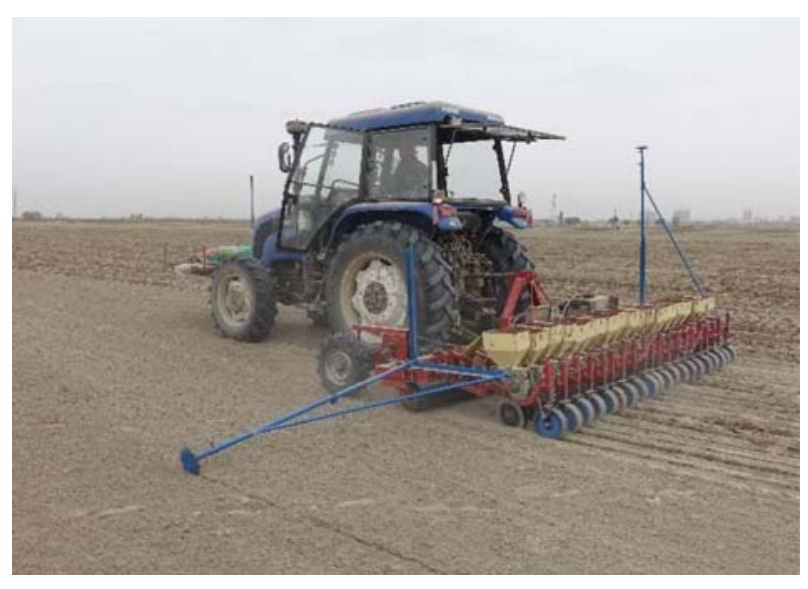

Figure 9 Field testing

Table 4 Measurement results of the sowing quality in the field

\begin{tabular}{|c|c|c|c|}
\hline \multicolumn{2}{|c|}{ Measured Index } & \multirow{2}{*}{$\begin{array}{c}\text { 1st Regiment } \\
\text { (2014) }\end{array}$} & \multirow{2}{*}{$\begin{array}{c}\text { 1st Regiment } \\
\text { (2015) } \\
23.5\end{array}$} \\
\hline \multirow{4}{*}{$\begin{array}{l}\text { Sowing depth } \\
\qquad / \mathrm{mm}\end{array}$} & Average Value & & \\
\hline & Standard Deviation & 12.7 & 14.1 \\
\hline & Variation Coefficient & 1.91 & 1.67 \\
\hline & Qualification Rate & 89.7 & 92.3 \\
\hline \multirow{4}{*}{$\begin{array}{l}\text { Hill spacing } \\
\text { /mm }\end{array}$} & Average Value & 104.21 & 103.37 \\
\hline & Standard Deviation & 19.74 & 26.86 \\
\hline & Variation Coefficient & 5.28 & 5.06 \\
\hline & Qualification Rate & 100 & 100 \\
\hline \multirow{4}{*}{$\begin{array}{l}\text { Line spacing } \\
\qquad / \mathrm{mm}\end{array}$} & Average Value & 98.4 & 97.2 \\
\hline & Standard Deviation & 5.11 & 4.71 \\
\hline & Variation Coefficient & 19.26 & 20.63 \\
\hline & Qualification Rate & 100 & 100 \\
\hline \multirow{4}{*}{$\begin{array}{l}\text { Seed number } \\
\text { per hill }\end{array}$} & Average Value & $14(13.71)$ & $14(13.53)$ \\
\hline & Standard Deviation & 2.41 & 1.43 \\
\hline & Variation Coefficient & 5.69 & 8.87 \\
\hline & Qualification Rate & 78 & 80 \\
\hline
\end{tabular}


According to Table 4, the production experiment with 2BDH-20 rice hill-drop drilling machine for dry land in XPCC for two consecutive years shows that all performance indexes of this machine satisfy the inspection standard specified in Operating Quality for the Grain Film-covering Hill-drop Drill.

\section{Conclusions}

1) A precision rice hill-drop drilling machine for dry land that integrates single profiling and hydraulic adjustment of hill spacing was developed to complete multiple operations including seedbed leveling, furrowing, seeding, hill spacing adjustment, and soil covering and pressing.

2) Through simulation analysis of the hydraulic system, this system was found applicable to real-time control on motor speed with an error of less than $15 \%$ while exporting stable and reliable torque. Thus, it can drive 20 seed metering devices to work simultaneously.

3) In the bench test, the operating speed should be within $2.8-3.2 \mathrm{~km} / \mathrm{h}$. The higher the seed conductor is, the poorer the hill formation becomes. Meanwhile, hill formation is also subject to the influence of wind resistance, framework vibration and seed bouncing.

4) Field test shows that when the $2 \mathrm{BDH}-2$ rice hill-drop drilling machine for dry land operates at a speed of 2.8-3.2 km/h, all inspection indexes will meet the requirements of the Operating Quality for Grain Film-covering Hill-drop Drill.

\section{[References]}

[1] Dai N. The development status and problems of mechanization production of rice. Modern Agricultural Equipment, 2014; 1: 16-20. (in Chinese)

[2] Huang J, Rozelle S, Rosegrant M W. China's food economy to the twenty-first century: Supply, demand, and trade. Economic Development and Cultural Change, 1999; 47(4): 737-766.

[3] Singh V, Jat M L, Ganie Z A, Chauhan B S, Gupta R K. Herbicide options for effective weed management in dry direct-seeded rice under scented rice-wheat rotation of western Indo-Gangetic Plains. Crop Protection, 2016; 81(361): 168-176.

[4] Mathankar S K, Saha K P, Rautaray S K, Singh V V. Development and evaluation of self-propelled rice ridge seeder for pre-germinated seeding. International Agricultural Engineering Journal, 2006; 15(2-3): 79-89.

[5] Bhushan L, Ladha J K, Gupta R K, Singh S, Tirol-Padre A, Saharawat Y S. Saving of water and labor in a rice-wheat system with no-tillage and direct seeding technologies. Agronomy Journal, 2007; 99(5): 1288-1296.

[6] Hill J E, Bayer D E, Bocchi S, Clampett W S. Direct seeded rice in the temperate climates of Australia, Italy, and the United States. Direct Seeded Flooded Rice in the Tropics: Selected Papers from the International Rice Research Conference, 27-31 August 1990, Seoul, Korea. Int. Rice Res. Inst., 1991. ISBN 971-22-0010-8

[7] Derpsch R, Friedrich T, Kassam A, Li H W. Current status of adoption of no-till farming in the world and some of its main benefits. Int J Agric \& Biol Eng, 2010; 3(1): 1-25.

[8] Kecskés M L, Choudhury A T M A, Casteriano A V, Deaker R, Roughley R J, Lewin L, et al. Effects of bacterial inoculant biofertilizers on growth, yield and nutrition of rice in Australia. Journal of Plant Nutrition, 2016; 39(3): 377-388.

[9] Cai D L. Manufacturing and test of accurate rice hill-drop planter. Nanjing: Nanjing Agricultural University, 2011. (in Chinese)

[10] Yao G X, Gao S, Chen S S. Research and progress of dry direct-seeding rice at home and abroad. Journal of Ningxia Agricultural College, 2003; 24(2): 63-67. (in Chinese)

[11] Devnani R S. Direct seeding options, equipment developed and their performance on yield of rice crop. AMA, Agricultural Mechanization in Asia, Africa and Latin America, 2002; 33(4): 27-33.

[12] Ahmed S, Salim M, Chauhan B S. Effect of weed management and seed rate on crop growth under direct dry seeded rice systems in Bangladesh. Plos One, 2014; 9(7): $1-10$.

[13] Wang Y F, Zhou Y H. Water-saving rice in northern China. Shenyang: Liao ning Science Press, 2000. (in Chinese)

[14] Tang X R, Luo X W, Li G X. Yield formation characteristics of precision hill-drop drilling early rice. Transactions of the CSAE, 2009; 25(7): 84-87. (in Chinese)

[15] Chen X H. The popularization and application practice of rice mechanization direct seeding for dry land. Agricultural Equipment Technology, 2007; 33(6): 48-49. (in Chinese)

[16] Zhao Y L, Feng W, Liu J S. Experience and demonstrating of new type rice dry direct seeder. Agricultural Engineering, 2014; 4(5): 15-19 (in Chinese)

[17] Wang F B, Liang N J, Yuan J. High - yielding and high-efficiency cultivation techniques of good rice variety. Wulumuqi: Xinjiang Science and Technology Press, 2012: 67-76. (in Chinese) 
[18] Xu Y M. The analysis and design of electro-hydraulic proportional control system. Beijing: China Machine Press, 2005; pp.117-118. (in Chinese)

[19] Saeys W, Wallays C, Engelen K, Ramon H, Anthonis J. An automatic depth control system for shallow slurry injection, Part 2: Control design and field validation. Biosystems Engineering, 2008; 99(2): 161-170.

[20] Uusitalo J. Introduction to forest operations and technology. JVP Forest Systems, 2010.

[21] Zeng S, Tang H T, Luo X W. Design and experiment of precision rice hill-drop drilling machine for dry land with synchronous fertilizing. Transactions of the CSAE, 2012;
28(20): 12-19. (in Chinese)

[22] Zhang B P. The design principle of seeding machinery. Beijing: China Machine Press, 1997; pp.291-297. (in Chinese)

[23] Dietrich J, Brajdic M, Walther K, Horn A, Kelbassa I. Investigation of increased drilling speed by online high-speed photography. Optics and Lasers in Engineering, 2008; 46(10): 705-710.

[24] Ma R J, Wang K Z, Ma X. Analysis of rice seedlings passing through separating chutes based on high speed photography technology. Transactions of the CSAM, 2011; 42(10): 84-89. (in Chinese) 